\title{
molecules
}

ISSN 1420-3049

www.mdpi.com/journal/molecules

Article

\section{RBAP, a Rhodamine B-Based Derivative: Synthesis, Crystal Structure Analysis, Molecular Simulation, and Its Application as a Selective Fluorescent Chemical Sensor for $\mathbf{S n}^{2+}$}

\author{
Xiaofeng Bao ${ }^{1, *}$, Xiaowei Cao ${ }^{1}$, Xuemei Nie ${ }^{2}$, Yanyan Jin ${ }^{1}$ and Baojing Zhou ${ }^{2}$ \\ 1 Department of Biochemical Engineering, Nanjing University of Science \& Technology, \\ Chemical Engineering Building B308, 200 Xiaolinwei, Nanjing 210094, China; \\ E-Mails: caoxiaowei518@126.com (X.C.); j.yy.1002c@163.com (Y.J.) \\ 2 Department of Chemistry, School of Chemical Engineering, Nanjing University of Science \& \\ Technology, Nanjing 210094, China; E-Mails: xuemeinie@163.com (X.N.); \\ bzhou@njust.edu.cn (B.Z.)
}

* Author to whom correspondence should be addressed; E-Mail: baoxiaofeng@mail.njust.edu.cn; Tel./Fax: +86-25-8431-5945.

Received: 18 April 2014; in revised form: 28 May 2014 / Accepted: 3 June 2014 /

Published: 11 June 2014

\begin{abstract}
A new fluorescent chemosensor based on a Rhodamine B and a benzyl 3-aminopropanoate conjugate (RBAP) was designed, synthesized, and structurally characterized. Its single crystal structure was obtained and analyzed by X-ray analysis. In a $\mathrm{MeOH} / \mathrm{H}_{2} \mathrm{O}(2: 3, \mathrm{v} / \mathrm{v}, \mathrm{pH}$ 5.95) solution RBAP exhibits a high selectivity and excellent sensitivity for $\mathrm{Sn}^{2+}$ ions in the presence of many other metal cations. The binding analysis using the Job's plot suggested the RBAP formed a 1:1 complex with $\mathrm{Sn}^{2+}$.
\end{abstract}

Keywords: rhodamine B; RBAP; Sn(II) ion; chemical sensor

\section{Introduction}

Selective and sensitive fluorescent sensors for the detection and quantification of transition-metal ions are widely attractive to current researchers because of their simplicity, high sensitivity and instantaneous response [1-7]. Conventional methods used to detect metal ions usually require large and expensive instruments and include atomic absorption/emission spectrometry [8-10], ion-coupled plasma emission-mass spectrometry [11] and X-ray fluorescence spectroscopy [12,13]. These 
instrumentally intensive methods often also require extensive sample preparation prior to analysis and sophisticated experimental procedures [14]. Thus, a simple and inexpensive method for detecting and quantifying metal ions is essential for real-time monitoring in biological samples. Ions of tin $(\mathrm{Sn})$, a type of heavy metal, are usually found in the environment at low levels. Humans are usually exposed to organic tin complexes through packaged foods, soft drinks, biocides, and dentifrices [15]. Little attention has been paid to the toxicity of $\mathrm{Sn}^{2+}$ as an environmental pollutant in natural waters. Although tin is not a highly toxic element [16], at high concentrations of approximately $0.1-1.0 \mathrm{~g} / \mathrm{L}$, $\mathrm{Sn}^{2+}$ may affect water flavor and cause diarrhea. Recent literature reports have revealed that, in forms such as $\mathrm{SnCl}_{2}, \mathrm{Sn}^{2+}$ can be readily taken up by human white blood cells and cause DNA damage [17,18]. Thus, it is desirable to develop a reliable and sensitive analytical method to qualitatively and quantitatively evaluate the level of $\mathrm{Sn}(\mathrm{II})$ ions present in environmental and biological systems. Rhodamine B derivatives are extensively employed as molecular probes in the study of complex biological systems due to their high absorption coefficients, high fluorescence quantum yields, and long-wavelength absorptions and emissions $[19,20]$. On the basis of the spirolactam/ring-opened amide equilibrium of rhodamine, several fluorescence-based sensing systems for metal ions have been developed. Most of the reported sensors based on rhodamine $\mathrm{B}$ derivatives are fluorescent chemosensors for the detection of $\mathrm{Pb}^{2+}, \mathrm{Cd}^{2+}, \mathrm{Cu}^{2+}, \mathrm{Fe}^{3+}$ and $\mathrm{Hg}^{2+}$ ions [21-29]. Unfortunately, to the best of our knowledge, only a few rhodamine B-based chemosensors have been reported for tin ions [30]. Therefore, a rhodamine B architecture was selected for the development of a new chemosensor that can selectively detect $\mathrm{Sn}^{2+}$. Recently, we reported rhodamine B-based sensor 1 (Figure 1), which consists of two rhodamine B moieties linked through the two amines of a 4,13-diaza-18-crown-6 ether as a highly sensitive fluorescent probe for monitoring $\mathrm{Cr}^{3+}$ in a $\mathrm{MeOH} / \mathrm{H}_{2} \mathrm{O}(3: 2, \mathrm{v} / \mathrm{v}, \mathrm{pH}$ 7.2) solution and in living cells [31]. Unfortunately, single crystals of sensor 1 could not be grown in the presence or absence of $\mathrm{Cr}^{3+}$ and were not analyzed by X-ray diffraction. In this paper, we report the design and synthesis of a rhodamine B-based derivative bearing a benzyl 3-aminopropanoate group (RBAP) that selectively displays a colorimetric response and a fluorescence "turn-on" response at $583 \mathrm{~nm}$ via a rhodamine ring-opening process with $\mathrm{Sn}^{2+}$ in the presence of many other metal ions. We also report the single crystal X-ray analysis of RBAP, which further confirms its structure in the absence of $\mathrm{Sn}^{2+}$. Additionally, a DFT computational study was carried out for better understanding of the formation of a complex between RBAP and $\mathrm{Sn}^{2+}$. To the best of our knowledge, RBAP is the first rhodamine B-based sensor for the $\mathrm{Sn}^{2+}$ ion utilizing the rhodamine ring-opening equilibrium approach.

Figure 1. Chemical structures of 1 and RBAP.

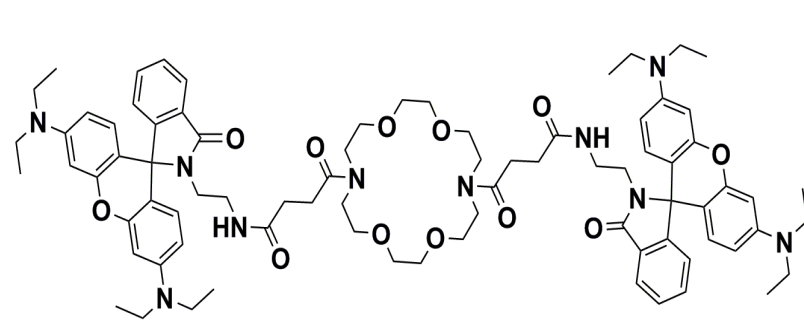

1

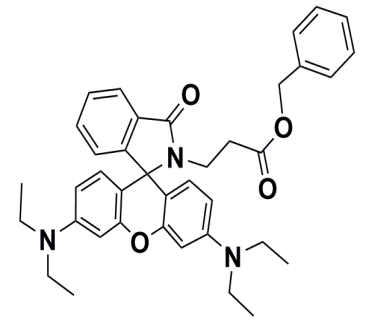

RBAP 


\section{Results and Discussion}

\subsection{Synthesis of $\boldsymbol{R} \boldsymbol{B} \boldsymbol{A P}$}

RBAP was synthesized according to the procedure published in the literature [31] (Scheme 1). Specifically, compound 2 was prepared in a 92\% yield by treating 1 with 3 -aminopropanoic acid and $\mathrm{HCl}$ gas at $120{ }^{\circ} \mathrm{C}$ for $12 \mathrm{~h}$, which was followed by coupling with rhodamine $\mathrm{B}$ in the presence of DCC (1 eq.), HOBt (1 eq.), and TEA ( 3 eq.) in $\mathrm{CH}_{2} \mathrm{Cl}_{2}$ at room temperature for $12 \mathrm{~h}$ to give $\mathbf{R B A P}$ in a $90 \%$ yield.

\section{Scheme 1. Synthesis of RBAP.}<smiles>OCc1ccccc1</smiles>

1<smiles>CCN(CC)c1ccc2c(-c3ccccc3C(=O)O)c3ccc(=[N+](CC)CC)cc-3oc2c1</smiles>

Rhodamine B

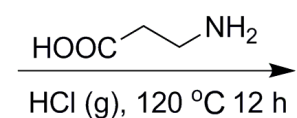

$\mathrm{HCl}(\mathrm{g}), 120^{\circ} \mathrm{C} 12 \mathrm{~h}$

i) $\mathrm{HOBt}, \mathrm{DCM}$

ii) TEA, 2, DCC, DCM, r.., $12 \mathrm{~h}$<smiles>O=C(CC[N]Cl)OCc1ccccc1</smiles>

2<smiles>CCN(CC)c1ccc2c(c1)Oc1cc(N(CC)CC)ccc1C21c2ccccc2C(=O)N1CCC(=O)OCc1ccccc1</smiles>

RBAP

\subsection{X-ray Crystallographic Analysis}

A single crystal of RBAP suitable for X-ray diffraction studies was grown by vapor diffusion of a $\mathrm{CH}_{2} \mathrm{Cl}_{2}$ solution of RBAP. The chemical structure of RBAP was further confirmed by X-ray analysis as shown in Figure 2, and the two-dimensional network structure of RBAP is shown in Figure 3.

Figure 2. Crystal structure of RBAP.

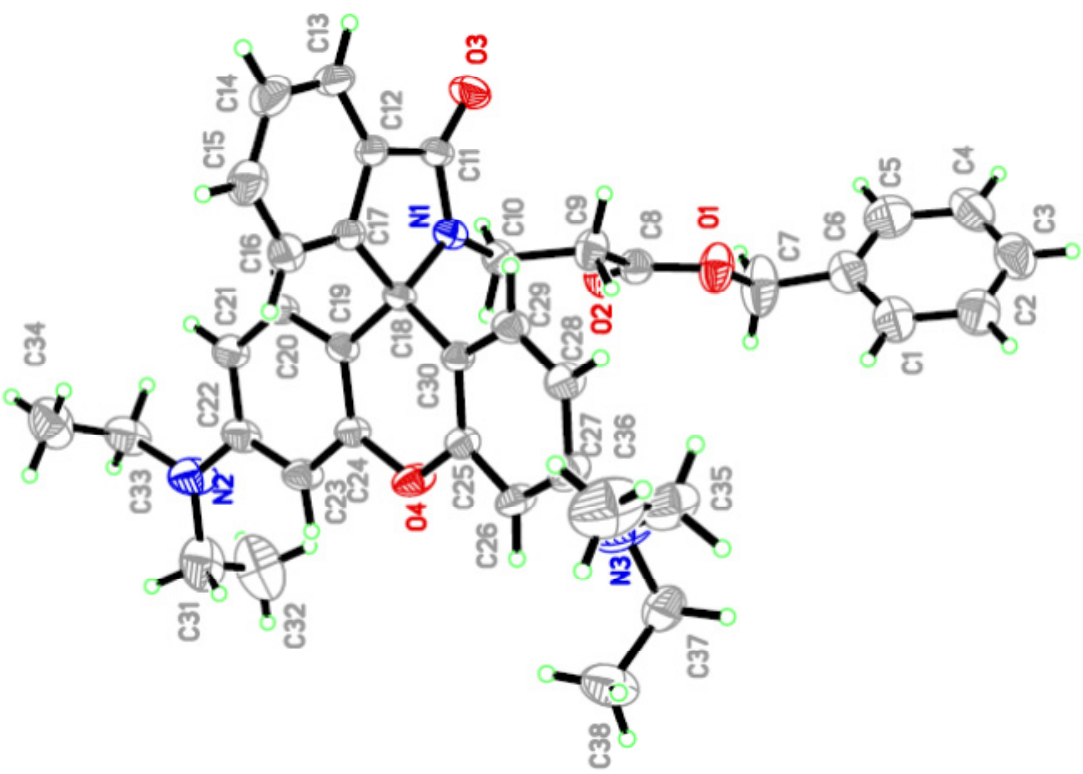


Figure 3. Network structure of RBAP.

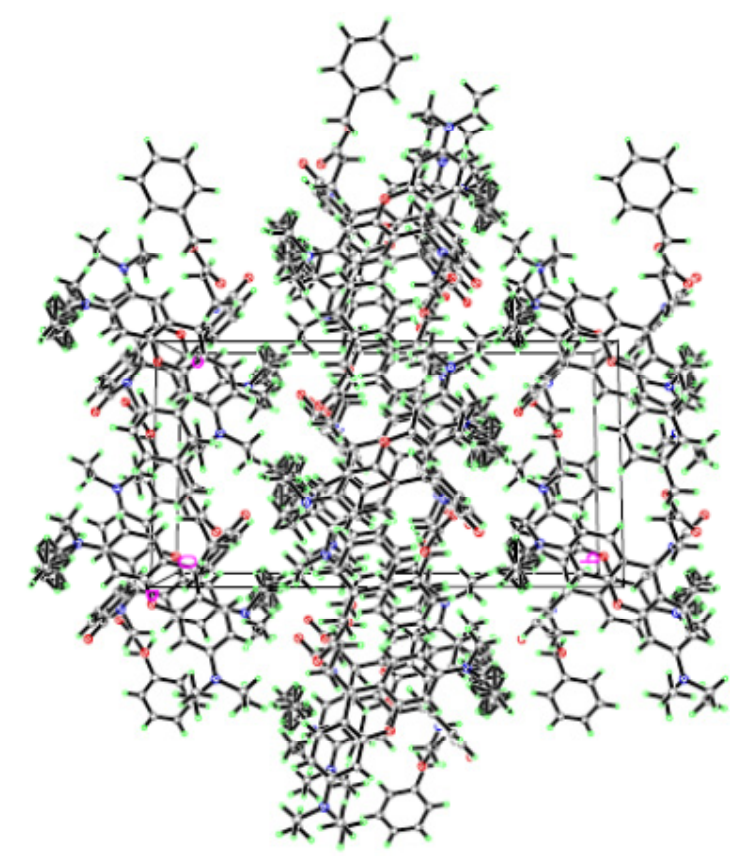

\section{3. pH Response of $\boldsymbol{R B} \boldsymbol{A P}$}

To evaluate the $\mathrm{pH}$ response of RBAP, acid-base titration experiments were performed in a $\mathrm{MeOH} / \mathrm{H}_{2} \mathrm{O}(2: 3, \mathrm{v} / \mathrm{v}, \mathrm{pH}$ 5.95) solution. The fluorescence intensities of RBAP at $583 \mathrm{~nm}$ in solutions at different $\mathrm{pH}$ levels were recorded. As shown in Figure 4, RBAP did not emit any obvious and characteristic fluorescence (excitation at $561 \mathrm{~nm}$ ) in the $\mathrm{pH}$ range of 5.0 to 12.0. However, the fluorescence intensity at $583 \mathrm{~nm}$ was obviously enhanced at $\mathrm{pH}$ levels below 5.0 due to the ring-opening mechanism of the spirocyclic moiety of rhodamine B (Scheme 2). These results suggested that RBAP was insensitive to $\mathrm{pH}$ from 5.0 to 12.0 and may have been able to sense $\mathrm{Sn}^{2+}$ under approximate physiological conditions with very low background fluorescence. Therefore, further $\mathrm{UV}-\mathrm{Vis}$ and fluorescence studies were carried out in a $\mathrm{MeOH} / \mathrm{H}_{2} \mathrm{O}(2: 3, \mathrm{v} / \mathrm{v}, \mathrm{pH}$ 5.95) solution.

Figure 4. The influence of $\mathrm{pH}$ on the fluorescence of RBAP in $\mathrm{MeOH} / \mathrm{H}_{2} \mathrm{O}$ solutions $(2: 3, \mathrm{v} / \mathrm{v}), \mathrm{pH}$ was modified by adding $10 \% \mathrm{HCl}$ or $10 \% \mathrm{NaOH}$.

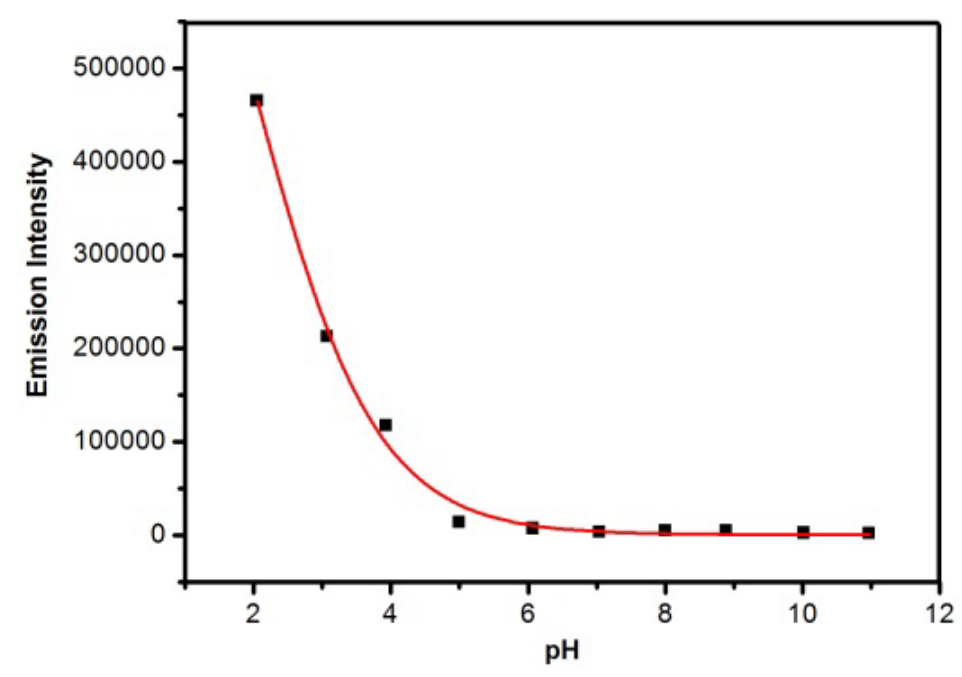


Scheme 2. Mechanism of RBAP response to $\mathrm{pH}$.
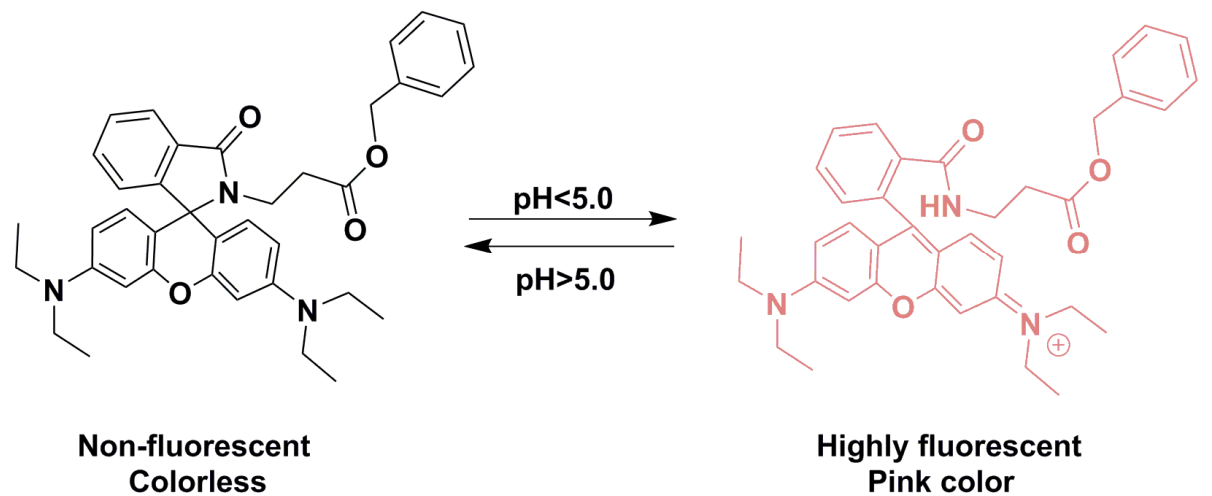

\subsection{UV-Vis Titration of $\boldsymbol{R B} \boldsymbol{A} \boldsymbol{P}$ with Metal Ions}

To evaluate the selectivity of RBAP for the $\mathrm{Sn}^{2+}$ ion, the binding behavior of RBAP toward different metal cations $\left(\mathrm{Mg}^{2+}, \mathrm{Sn}^{2+}, \mathrm{Cr}^{3+}, \mathrm{Ag}^{+}, \mathrm{Ca}^{2+}, \mathrm{Na}^{+}, \mathrm{Pb}^{2+}, \mathrm{K}^{+}, \mathrm{Mn}^{2+}, \mathrm{Zn}^{2+}, \mathrm{Cu}^{2+}, \mathrm{Cd}^{2+}, \mathrm{Li}^{+}, \mathrm{Ba}^{2+}\right.$, $\mathrm{Fe}^{2+}, \mathrm{Co}^{2+}, \mathrm{Fe}^{3+}, \mathrm{Hg}^{2+}, \mathrm{Al}^{3+}, \mathrm{Sn}^{4+}$ ) was studied by $\mathrm{UV}-\mathrm{V}$ is spectroscopy. All measurements were made according to the following procedure. Test samples were prepared by placing five equivalents of a metal ion stock solution into $10 \mu \mathrm{M}$ RBAP in $\mathrm{MeOH} / \mathrm{H}_{2} \mathrm{O}(2: 3, \mathrm{v} / \mathrm{v}, \mathrm{pH} 5.95)(3 \mathrm{~mL})$ and UV absorption spectra were measured $30 \mathrm{~min}$ after metal ion addition. All titration experiments were recorded at room temperature. The absorption wavelength for RBAP was $561 \mathrm{~nm}$. Of the various metal cations examined, RBAP showed a highly selective "off-on" absorption enhancement with $\mathrm{Sn}^{2+}$ at $561 \mathrm{~nm} . \mathrm{Cr}^{3+}$ also resulted in a small absorbance at $561 \mathrm{~nm}$, but at a 3-fold lower intensity than $\mathrm{Sn}^{2+}$. All other metal cations yielded very little absorbance at $561 \mathrm{~nm}$ (Figure 5).

Figure 5. UV-Vis spectra of RBAP $(10 \mu \mathrm{M})$ in $\mathrm{MeOH} / \mathrm{H}_{2} \mathrm{O}(2: 3, \mathrm{v} / \mathrm{v}, \mathrm{pH} 5.95)$ in the presence and absence of metal cations $\left(50 \mu \mathrm{M}, 5.0\right.$ equiv.): $\mathrm{Mg}^{2+}, \mathrm{Sn}^{2+}, \mathrm{Cr}^{3+}, \mathrm{Ag}^{+}, \mathrm{Ca}^{2+}$, $\mathrm{Na}^{+}, \mathrm{Pb}^{2+}, \mathrm{K}^{+}, \mathrm{Mn}^{2+}, \mathrm{Zn}^{2+}, \mathrm{Cu}^{2+}, \mathrm{Cd}^{2+}, \mathrm{Li}^{+}, \mathrm{Ba}^{2+}, \mathrm{Fe}^{2+}, \mathrm{Co}^{2+}, \mathrm{Fe}^{3+}, \mathrm{Hg}^{2+}, \mathrm{Al}^{3+}$ and $\mathrm{Sn}^{4+}$.

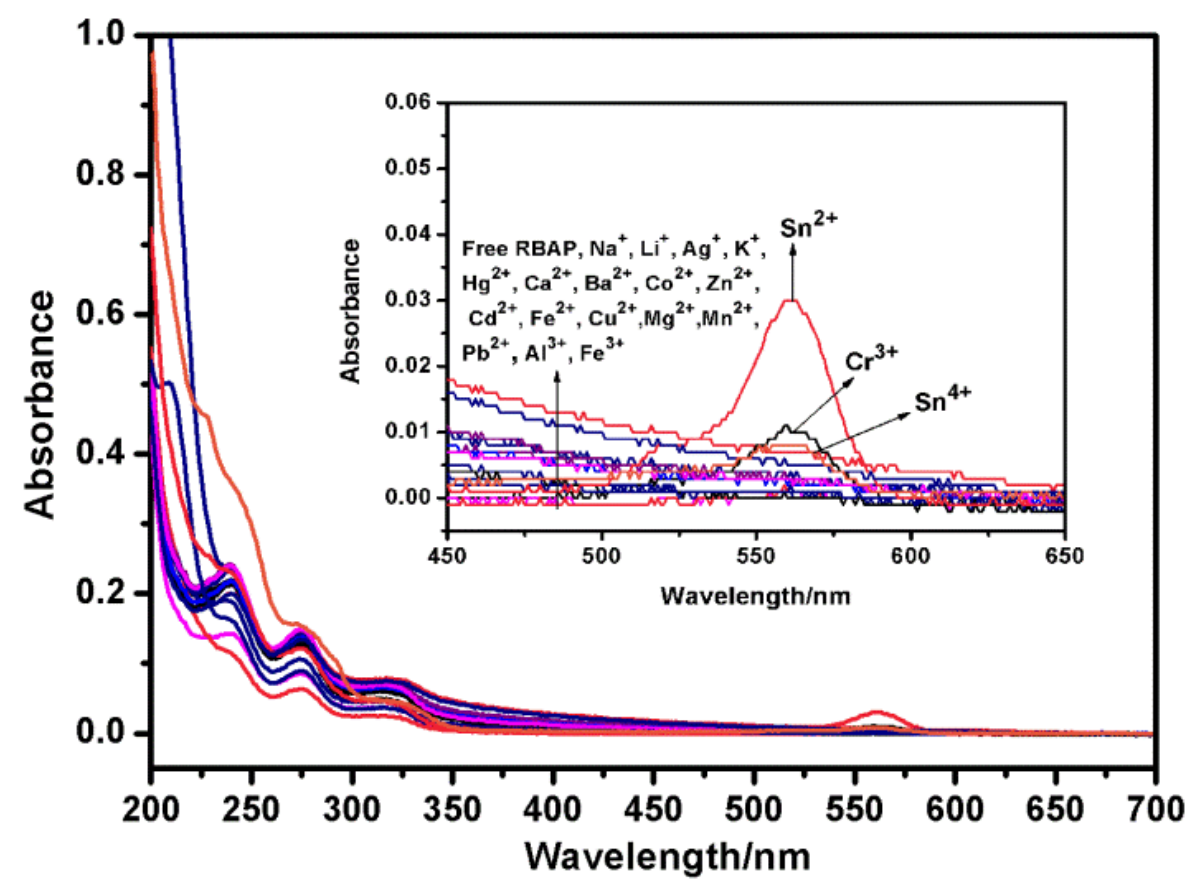


The absorption spectra of RBAP upon titration with $\mathrm{Sn}^{2+}$ in $\mathrm{MeOH} / \mathrm{H}_{2} \mathrm{O}(2: 3, \mathrm{v} / \mathrm{v}, \mathrm{pH}$ 5.95) solution were recorded to gain further insight into the binding of RBAP and $\mathrm{Sn}^{2+}$. When no $\mathrm{Sn}^{2+}$ ions were added to the solution of RBAP, the free RBAP remained colorless and did not exhibit any apparent absorption above $400 \mathrm{~nm}$ in $\mathrm{MeOH} / \mathrm{H}_{2} \mathrm{O}(2: 3, \mathrm{v} / \mathrm{v}, \mathrm{pH}$ 5.95) solution, indicating that the spirolactam form of RBAP was the predominant species. Upon addition of the $\mathrm{Sn}^{2+}$ ion, a new and strong absorption band centered at $561 \mathrm{~nm}$ was observed (Figure 6), resulting in the color change from colorless to pink. This indicated that the ring-opened form of RBAP exists in a significant concentration in the examined solution (Scheme 2).

Figure 6. Changes in the UV-Vis absorption spectra of RBAP $(10 \mu \mathrm{M})$ in $\mathrm{MeOH} / \mathrm{H}_{2} \mathrm{O}$ (2:3, v/v, $\mathrm{pH} 5.95)$ solutions containing various amounts of $\mathrm{Sn}^{2+}$ ions (0-15 eq.). Inset: Absorbance of RBAP at $561 \mathrm{~nm}$ as a function of $\mathrm{Sn}^{2+}$ concentration.

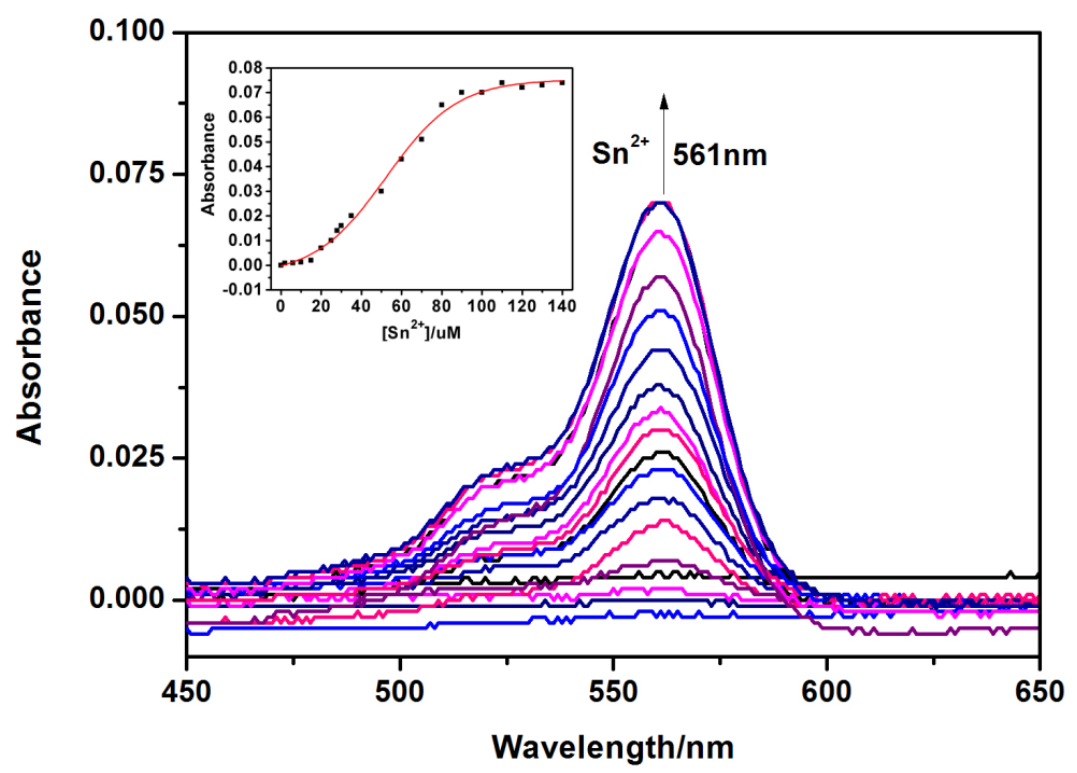

Figure 7. Job's plot of RBAP in a $\mathrm{MeOH} / \mathrm{H}_{2} \mathrm{O}(2: 3$, v/v) solution, with a total concentration of $[\mathbf{R B A P}]+\mathrm{Sn}^{2+}=100 \mu \mathrm{M}$ and a detection wavelength of $561 \mathrm{~nm}$.

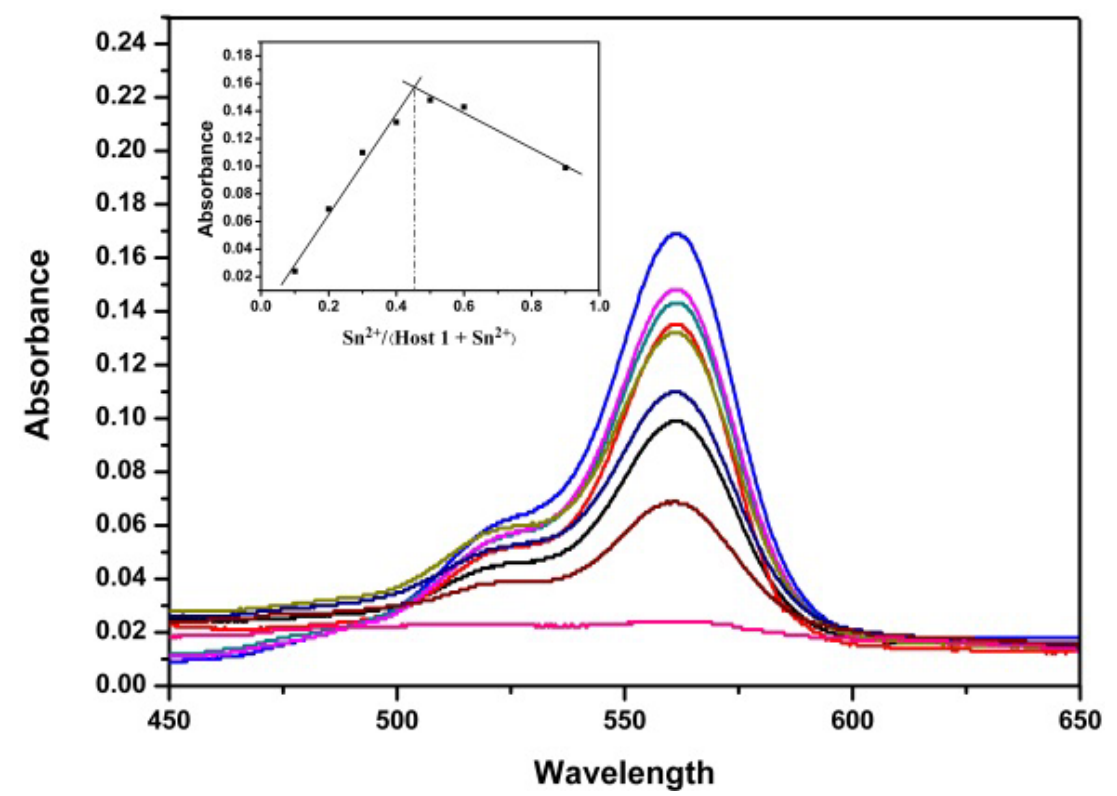


Next, a Job's plot was generated by continuously varying the mole fraction of $\mathrm{Sn}^{2+}$ from 0 to 1 in a solution of $\left[\mathrm{Sn}^{2+}\right]+[\mathbf{R B A P}]$ with a total concentration of $100 \mu \mathrm{M}$. The Job's plot analysis exhibited a maximum at approximately 0.5 mole fraction, indicating a $1: 1$ stoichiometry for the RBAP-Sn ${ }^{2+}$ complex (Figure 7 inset).

\subsection{Fluorescence Titration of RBAP with Metal Ions}

To further evaluate the selectivity of RBAP for $\mathrm{Sn}^{2+}$, the change in fluorescence intensity upon the addition of various metal ions under the same conditions was also investigated. The fluorescence spectra of RBAP $(10 \mu \mathrm{M})$ in $\mathrm{MeOH} / \mathrm{H}_{2} \mathrm{O}(2: 3, \mathrm{v} / \mathrm{v}, \mathrm{pH}$ 5.95) displayed a very weak fluorescence at $583 \mathrm{~nm}\left(\lambda_{\mathrm{ex}}=561 \mathrm{~nm}\right)$, indicating that the predominant form of RBAP was the spirolactam form. When $\mathrm{Sn}^{2+}$ (50 $\mu \mathrm{M}, 5$ equiv.) was added to the RBAP solution, a fluorescence enhancement of greater than 300-fold was observed (Figure 8), indicating that the $\mathrm{Sn}^{2+}$ ion induced the formation of the ring-opened RBAP-Sn ${ }^{2+}$ complex, which exhibited strong fluorescence (Scheme 3) The solution changed from colorless to pink. (Figure 8 inset) other various metal ions $\left(\mathrm{Mg}^{2+}, \mathrm{Sn}^{2+}, \mathrm{Cr}^{3+}, \mathrm{Ag}^{+}, \mathrm{Ca}^{2+}\right.$, $\mathrm{Na}^{+}, \mathrm{Pb}^{2+}, \mathrm{K}^{+}, \mathrm{Mn}^{2+}, \mathrm{Zn}^{2+}, \mathrm{Cu}^{2+}, \mathrm{Cd}^{2+}, \mathrm{Li}^{+}, \mathrm{Ba}^{2+}, \mathrm{Fe}^{2+}, \mathrm{Co}^{2+}, \mathrm{Fe}^{3+}, \mathrm{Hg}^{2+}, \mathrm{Al}^{3+}$ and $\mathrm{Sn}^{4+}$ ) did not induce any apparent fluorescence enhancement after the addition of five equiv. of the metal ions.

Figure 8. Fluorescence emission changes of RBAP $(10 \mu \mathrm{M})$ with metal cations $(50 \mu \mathrm{M}$, 5.0 equiv.) in $\mathrm{MeOH} / \mathrm{H}_{2} \mathrm{O}(2: 3, \mathrm{v} / \mathrm{v}, \mathrm{pH} 5.95)$ at $583 \mathrm{~nm}$, Black bars represent the fluorescence intensity of RBAP with: 1-none; $2-\mathrm{Sn}^{2+} ; 3-\mathrm{Cr}^{3+} ; 4-\mathrm{Ca}^{2+} ; 5-\mathrm{Ag}^{+} ; 6-\mathrm{Mg}^{2+} ; 7-\mathrm{K}^{+}$; $8-\mathrm{Ba}^{2+} ; 9-\mathrm{Co}^{2+} ; 10-\mathrm{Zn}^{2+} ; 11-\mathrm{Li}^{+} ; 12-\mathrm{Cd}^{2+} ; 13-\mathrm{Fe}^{2+} ; 14-\mathrm{Cu}^{2+} ; 15-\mathrm{Mn}^{2+} ; 16-\mathrm{Pb}^{2+} ; 17-\mathrm{Na}^{+}$, $18-\mathrm{Fe}^{3+}, 19-\mathrm{Hg}^{2+}, 20-\mathrm{Al}^{3+}, 21-\mathrm{Sn}^{4+}$.
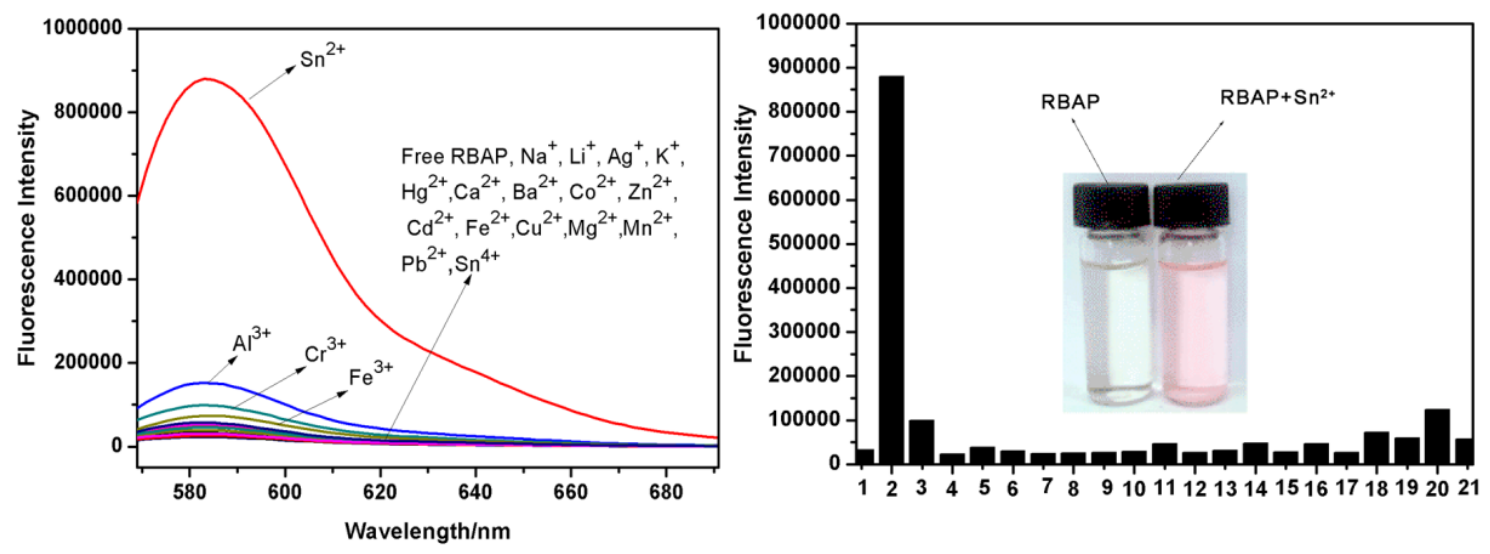

Scheme 3. Proposed complexation mechanism of RBAP with $\mathrm{Sn}^{2+}$.

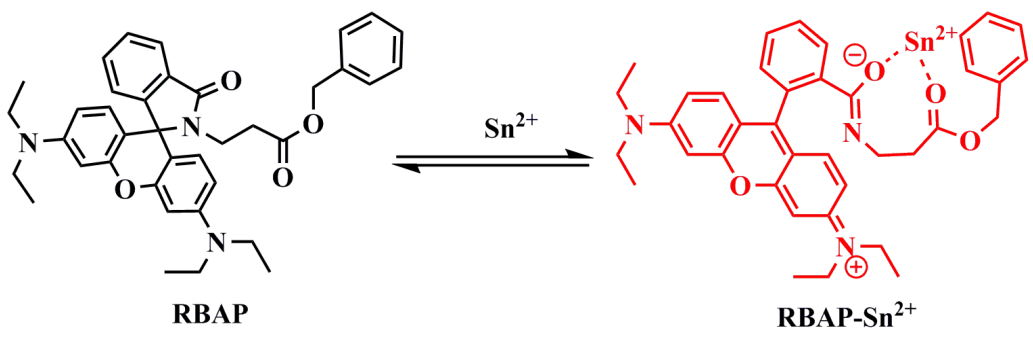

Non-fluorescent

Colorless
Highly fluorescent

Pink color 


\subsection{Fluorescence Titration of RBAP with $\mathrm{Sn}^{2+}$}

Figure 9 displays the fluorescence spectrum of RBAP in the presence of different concentrations of $\mathrm{Sn}^{2+}$. The free RBAP chemosensor $(10 \mu \mathrm{M})$ exhibited a very weak fluorescence $\left(\lambda_{\mathrm{ex}}=561 \mathrm{~nm}\right)$ at $583 \mathrm{~nm}$. The titration of $\mathrm{Sn}^{2+}$ with RBAP led to a rapid increase in the emission intensity at $583 \mathrm{~nm}$. Over a 300-fold fluorescence enhancement was observed under saturation conditions (10 equiv.). The association constant was also calculated using the following formula: $\mathrm{F}-\mathrm{F}_{0}=\Delta \mathrm{F}=\left[\mathrm{Sn}^{2+}\right]$ $\left(\mathrm{F}_{\max }-\mathrm{F}_{0}\right) /\left(1 / \mathrm{K}_{\mathrm{a}}+\left[\mathrm{Sn}^{2+}\right]\right)$ based on a $1: 1$ stoichiometry, where $\mathrm{F}$ is the obtained fluorescence intensity, $F_{0}$ is the fluorescence intensity of free RBAP at the emission wavelength, and $F_{\max }$ is the saturated fluorescence intensity for RBAP- $\mathrm{Sn}^{2+}$ complex. When the reciprocal of $\Delta \mathrm{F}$ was plotted as a function of $\mathrm{Sn}^{2+}$ concentration, a linear relationship was obtained $(\mathrm{y}=\mathrm{A}+\mathrm{Bx})$, and $\mathrm{K}_{\mathrm{a}}$ was calculated from A/B. Therefore, the binding association constant for $\mathrm{Sn}^{2+}, \mathrm{K}_{\mathrm{a}}$, was estimated to be $2.65 \times 10^{4} \mathrm{M}^{-1}$ in the $\mathrm{MeOH} / \mathrm{H}_{2} \mathrm{O}(2: 3, \mathrm{v} / \mathrm{v}, \mathrm{pH}$ 5.95) solution, as inferred from the fluorescence titration curves of RBAP with the $\mathrm{Sn}^{2+}$ ion. The detection limit of $\mathrm{Sn}^{2+}$ by RBAP was determined to be $0.044 \mu \mathrm{M}$ (Supporting Materials, S5).

Figure 9. Changes in the fluorescence intensity of RBAP in $\mathrm{MeOH} / \mathrm{H}_{2} \mathrm{O}(2: 3, \mathrm{v} / \mathrm{v}$, $\mathrm{pH}$ 5.95) upon the addition of $\mathrm{Sn}^{2+} . \lambda_{\mathrm{ex}}=561 \mathrm{~nm}$. Inset: Plot of fluorescence intensities at $583 \mathrm{~nm}$ upon the addition of $\mathrm{Sn}^{2+}$.

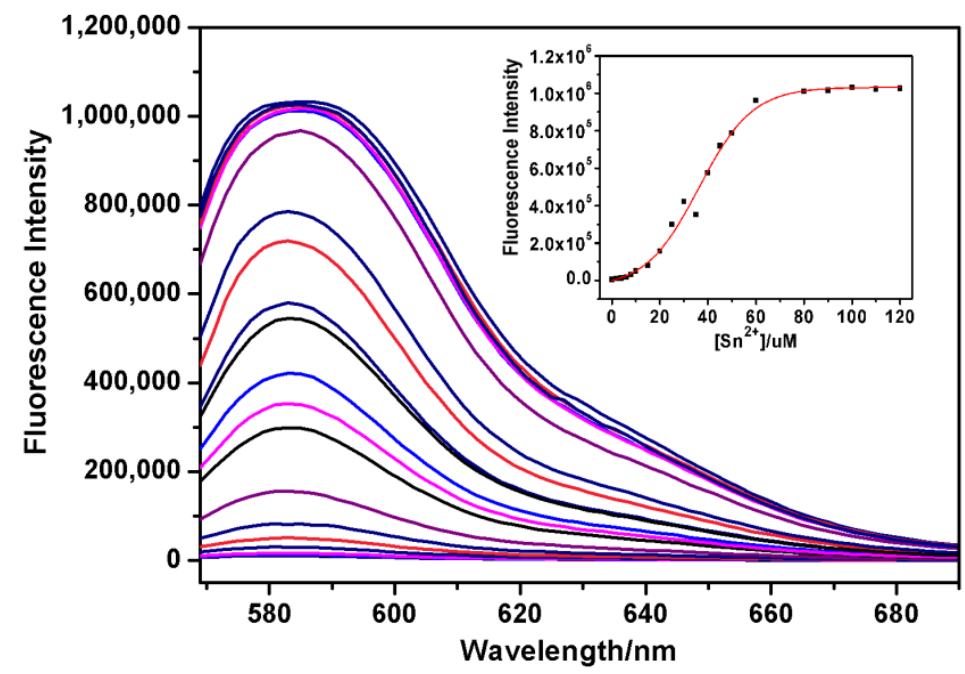

\subsection{NMR Study of RBAP with $\mathrm{Sn}^{2+}$}

To further elucidate the binding mode of RBAP with $\mathrm{Sn}^{2+},{ }^{1} \mathrm{H}-\mathrm{NMR}$ spectra of RBAP in the presence and absence of $\mathrm{Sn}^{2+}$ were acquired. As shown in Figure 10, after the addition of 1 equiv. of $\mathrm{Sn}^{2+}$ into a solution of RBAP in acetone- $d_{6}: \mathrm{D}_{2} \mathrm{O}(5: 1, \mathrm{v} / \mathrm{v})$, The singlet peak of $\mathrm{H}_{\mathrm{f}}$ proton displayed a downfield shift from $4.15 \mathrm{ppm}$ to $4.21 \mathrm{ppm}(\Delta \delta=0.06 \mathrm{ppm})$, which originates from the coordination

of the carbonyl oxygen of ester group on RBAP with $\mathrm{Sn}^{2+}$. In addition, the $\mathrm{H}_{\mathrm{g}}$ multiplet, (the signals of $\mathrm{H}_{\mathrm{g} 1}$ and $\mathrm{H}_{\mathrm{g} 2}$ overlapped) displayed an apparent downfield shift and signal splitting from one multiplet peak centered at $3.41 \mathrm{ppm}$ to two multiplet peaks centered at $3.65 \mathrm{ppm}(\Delta \delta=0.24 \mathrm{ppm})$ and $3.50 \mathrm{ppm}$ $(\Delta \delta=0.09 \mathrm{ppm})$, and the singlet peak of the symmetric $\mathrm{H}_{\mathrm{e}}$ proton also displayed a significant downfield shift and signal splitting, from a peak centered at $6.4 \mathrm{ppm}$ to three doublets peaks centered 
at $6.78 \mathrm{ppm}(\Delta \delta=0.38 \mathrm{ppm}), 7.0 \mathrm{ppm}(\Delta \delta=0.60 \mathrm{ppm})$ and $7.31 \mathrm{ppm}(\Delta \delta=0.91 \mathrm{ppm})$, due to the $\mathrm{Sn}^{2+}$ ion-induced ring-opening process of the rhodamine B spirocycle. (Supporting Materials Figure S3). The above results indicate an interaction mode of RBAP and $\mathrm{Sn}^{2+}$ as proposed in Scheme 3, in which $\mathrm{Sn}^{2+}$ is coordinated with the two carbonyl oxygen atoms of RBAP.

Figure 10. ${ }^{1} \mathrm{H}-\mathrm{NMR}$ spectra $\left(500 \mathrm{MHz}, 298 \mathrm{~K}\right.$, acetone- $d_{6}: \mathrm{D}_{2} \mathrm{O}(5: 1, \mathrm{v} / \mathrm{v})$ of (a) RBAP and (b) RBAP +1 equiv. $\mathrm{Sn}^{2+}$.

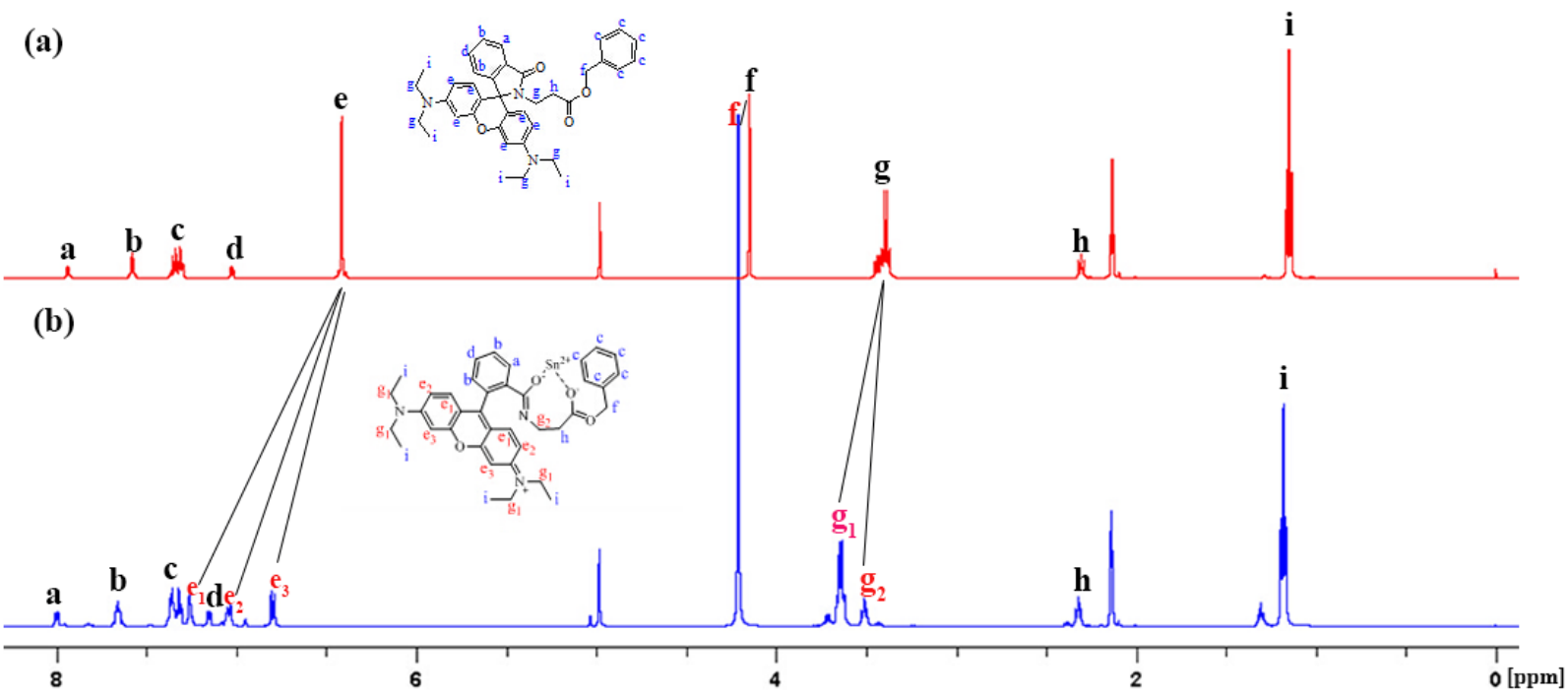

\subsection{Density Functional Theory (DFT) Calculations}

For better understanding of the nature of $\mathrm{Sn}^{2+}$ coordination with RBAP, energy optimized structures of RBAP and RBAP-Sn ${ }^{2+}$ (Figure 11) were obtained using DFT calculations with the B3LYP method using $6-31+\mathrm{G}(\mathrm{d})$ as a basis set.

Figure 11. Energy-minimized structure of (A) RBAP and the (B) RBAP-Sn ${ }^{2+}$ complex.

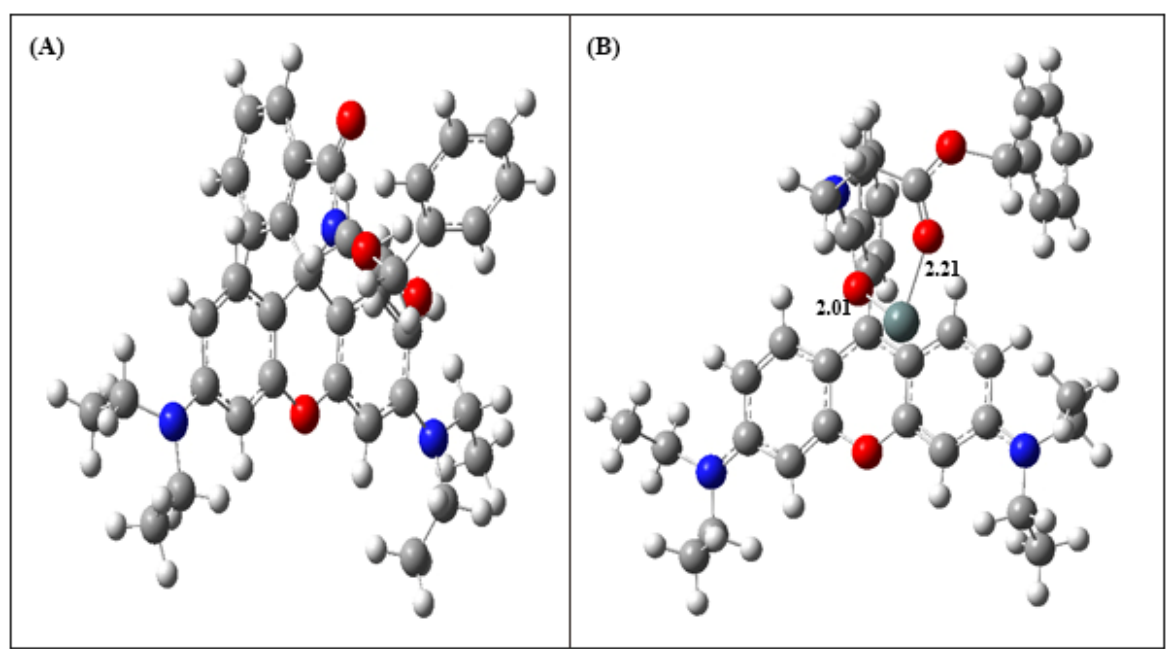

The spatial distributions and orbital energies of the HOMO and LUMO of RBAP and RBAP-Sn ${ }^{2+}$ were also generated using DFT calculations (Figure 12). The results indicated that, in RBAP the HOMO is spread out on the xanthenes of the rhodamine B moiety, while the LUMO is centered on the 
spirocycle of the rhodamine B moiety and more localized. As a result, the $\mathrm{C}-\mathrm{N}$ bond on the spirocycle of the rhodamine $\mathrm{B}$ moiety breaks to facilitate the binding of $\mathrm{Sn}^{2+}$ ions with the two RBAP carbonyl oxygen atoms. The $\pi$ electrons in the HOMO of the RBAP- $\mathrm{Sn}^{2+}$ complex are mainly located in rhodamine $\mathrm{B}$, while the LUMO is mostly located on the guest $\mathrm{Sn}^{2+}$ ion. The energy gap between the HOMO and LUMO was calculated to be $55.74 \mathrm{kcal} / \mathrm{mol}$, an almost $50 \%$ decrease from that of RBAP, which was $102.38 \mathrm{kcal} / \mathrm{mol}$ (Supporting Materials). The results clearly suggest that the binding of $\mathrm{Sn}^{2+}$ to RBAP stabilizes the system because the calculated orbital energies of both the HOMO and LUMO were lowered for the complex. In the RBAP-Sn ${ }^{2+}$ complex, the distances of the two "Sn-O" bonds were calculated to be 2.01 and $2.21 \AA$, respectively (Figure 11).

Figure 12. HOMO and LUMO orbitals of (A) RBAP and the (B) RBAP-Sn ${ }^{2+}$ complex.

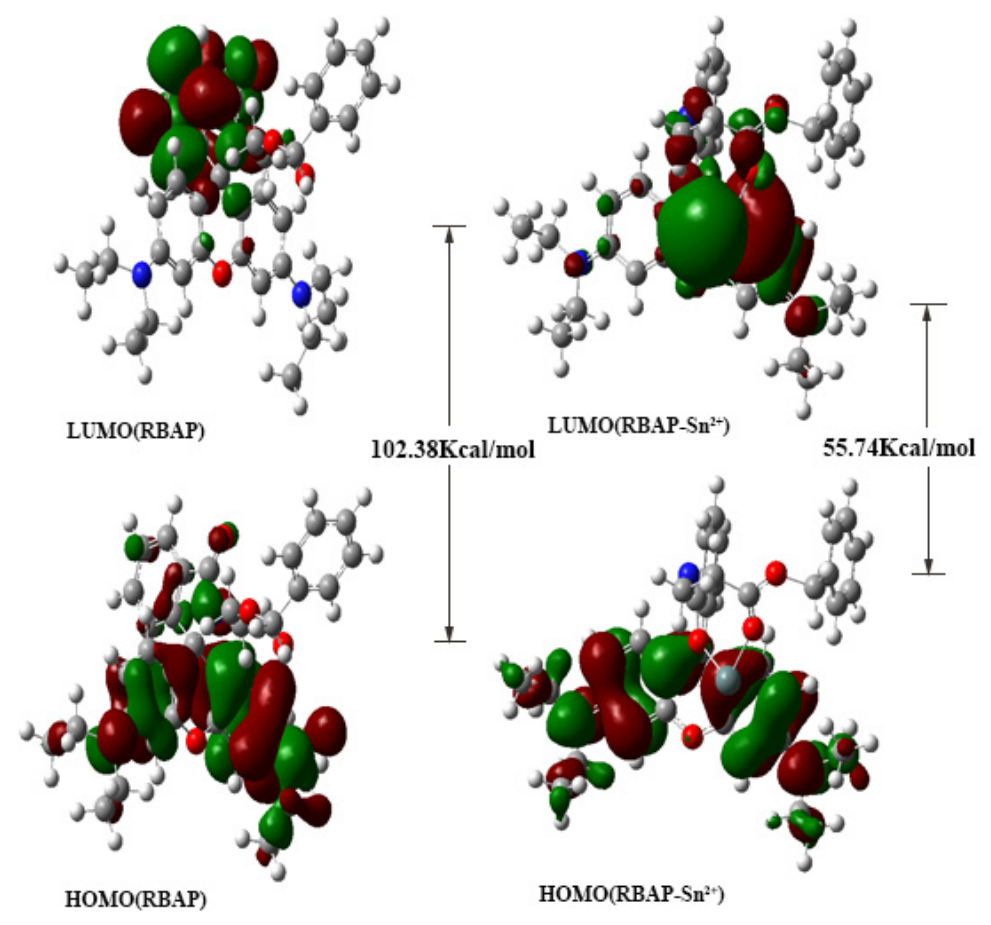

\section{Experimental Section}

\subsection{Materials and General Methods}

All reagents and organic solvents were ACS grade or higher and were used without further purification. Unless otherwise noted, all chemicals were purchased from J\&K Scientific (Shanghai, China) and were used as received. All solvents were of analytical grade, and double distilled water was used in all experiments. The salts used to prepare metal ion stock solutions were $\mathrm{Ba}\left(\mathrm{NO}_{3}\right)_{2}, \mathrm{AgNO}_{3}$, $\mathrm{NaCl}, \mathrm{LiCl} \cdot \mathrm{H}_{2} \mathrm{O}, \mathrm{KCl}, \quad \mathrm{MgCl}_{2} \cdot 6 \mathrm{H}_{2} \mathrm{O}, \quad \mathrm{FeCl}_{3} \cdot 6 \mathrm{H}_{2} \mathrm{O}, \quad \mathrm{SnCl}_{2} \cdot 2 \mathrm{H}_{2} \mathrm{O}, \mathrm{CuCl}_{2} \cdot 2 \mathrm{H}_{2} \mathrm{O}, \mathrm{CaCl}_{2}, \quad \mathrm{PbCl}_{2}$, $\mathrm{MnCl}_{2} \cdot 4 \mathrm{H}_{2} \mathrm{O}, \mathrm{ZnCl}_{2}, \mathrm{CdCl}_{2} \cdot 2.5 \mathrm{H}_{2} \mathrm{O}, \mathrm{FeCl}_{2} \cdot 4 \mathrm{H}_{2} \mathrm{O}, \mathrm{HgCl}_{2}, \mathrm{AlCl}_{3}, \mathrm{CoCl}_{2} \cdot 6 \mathrm{H}_{2} \mathrm{O}, \mathrm{SnCl}_{4}$ and $\mathrm{CrCl}_{3} \cdot 6 \mathrm{H}_{2} \mathrm{O}$. The reactions were performed under an argon atmosphere using standard Schlenk techniques. Thin-layer chromatography was performed on a HAIYANG silica gel F254 plate, and compounds were visualized under UV light $(\lambda=254 \mathrm{~nm})$. Column chromatography was performed using HAIYANG silica gel (type: 200-300 mesh ZCX-2). 
${ }^{1} \mathrm{H}(500 \mathrm{MHz})$ and ${ }^{13} \mathrm{C}-\mathrm{NMR}(126 \mathrm{MHz})$ spectra were recorded on an Avance 500 spectrometer (Bruker; Billerica, MA, USA). The chemical shifts are reported in $\delta$ units ( $\mathrm{ppm}$ ) downfield relative to the chemical shift of tetramethylsilane. The abbreviations br, s, d, t, and $\mathrm{m}$ denote broad, singlet, doublet, triplet, and multiplet, respectively. Mass spectra were obtained with a Finnigan TSQ Quantum LC/MS Spectrometer (Thermo Fisher Scientific Corp., Waltham, MA, USA). High-resolution mass spectra (HRMS) were acquired under electron ionization conditions with a double-focusing high-resolution instrument (Thermo Fisher Scientific Corp., Waltham, MA, USA) The pH levels of stock solutions were measured using a PHS-25C Precision $\mathrm{pH} / \mathrm{mV}$ Meter (Aolilong, Hangzhou, China). UV-Vis and fluorescence spectra were obtained on a UV-3600 UV-VIS-NIR spectrophotometer (Shimadzu, Kyoto, Japan) and an Edinburgh FLS920 fluorescence spectrophotometer (Livingston, UK), respectively at room temperature.

\subsection{Synthesis of 3-(Benzyloxy)-3-oxopropan-1-aminium chloride (2)}

$\beta$-Alanine (2.9 g, $32.5 \mathrm{mmol}$ ) was suspended in $20 \mathrm{~mL}$ of phenylmethanol. Hydrogen chloride was passed through the solution for $15 \mathrm{~min}$ at room temperature. The reaction mixture was stirred at $120{ }^{\circ} \mathrm{C}$ for $12 \mathrm{~h}$, cooled to room temperature, and then dried under vacuum. Flash chromatography (silica gel; $\left.\mathrm{MeOH} / \mathrm{DCM}, 5: 95, \mathrm{v} / \mathrm{v} ; \mathrm{R}_{\mathrm{f}}=0.3\right)$ of the residue gave 2 as a white solid $(6.45 \mathrm{~g}, 92 \%) .{ }^{1} \mathrm{H}-\mathrm{NMR}(\mathrm{CDCl} 3)$ : $\delta=7.72(\mathrm{~s}, 1 \mathrm{H}), 7.29-7.25(\mathrm{~m}, 5 \mathrm{H}), 5.09(\mathrm{~s}, 2 \mathrm{H}), 3.35(\mathrm{t}, J=5.5 \mathrm{~Hz}, 2 \mathrm{H}), 2.92(\mathrm{t}, J=6.5 \mathrm{~Hz}, 2 \mathrm{H})$.

\subsection{Synthesis of Benzyl 3-(3',6'-bis(diethylamino)-3-oxospiro[isoindoline-1,9'-xanthen]-2-yl) propan oate ( $\boldsymbol{R B} \boldsymbol{A} \boldsymbol{P})$}

A solution of $2(2.00 \mathrm{~g}, 10 \mathrm{mmol})$ and $\mathrm{Et}_{3} \mathrm{~N}(1.5 \mathrm{~mL}, 10.8 \mathrm{mmol})$ in $20 \mathrm{~mL} \mathrm{CH}_{2} \mathrm{Cl}_{2}$ was added to a solution of Rhodamine B $(4.00 \mathrm{~g}, 8.3 \mathrm{mmol})$ and $\mathrm{HOBt}(1.2 \mathrm{~g}, 8.9 \mathrm{mmol})$ in $30 \mathrm{~mL} \mathrm{CH}_{2} \mathrm{Cl}_{2}$. The reaction mixture was stirred at room temperature for $12 \mathrm{~h}$, filtered through a pad of Celite and then dried under vacuum. Flash chromatography (silica gel; $\mathrm{MeOH} / \mathrm{DCM}, 2 / 98, \mathrm{v} / \mathrm{v} ; \mathrm{R}_{\mathrm{f}}=0.3$ ) of the residue gave RBAP as a bright-red solid (4.51 g, 90\%). ${ }^{1} \mathrm{H}-\mathrm{NMR}$ (acetone- $\left.d_{6} / \mathrm{D}_{2} \mathrm{O}\right): \delta=7.94-7.92(\mathrm{~m}, 1 \mathrm{H})$, 7.58-7.56 (m, 2H), 7.36-7.29 (m, 5H), 7.03-7.01 (m, 1H), 6.43-6.39 (m, 6H), $4.98(\mathrm{~s}, 2 \mathrm{H}), 3.45-3.37$ (m, 10H), 2.30 (t, $J=7.75 \mathrm{~Hz}, 2 \mathrm{H}), 1.15(\mathrm{t}, J=7.0 \mathrm{~Hz}, 12 \mathrm{H}) \mathrm{ppm} .{ }^{13} \mathrm{C}-\mathrm{NMR}\left(126 \mathrm{MHz}, \mathrm{CDCl}_{3}, 298 \mathrm{~K}\right)$ : $\delta=171.6,168.2,153.9,153.4,148.9,136.0,132.5,130.9,128.9,128.5,128.2,128.0,123.8,122.9$, $108.3,105.4,98.2,66.2,65.0,44.5,35.9,32.9,29.8,12.7$ ppm. ESI-MS (m/s): Calculated for $[\mathrm{M}+\mathrm{H}]^{+}$ $\mathrm{C}_{38} \mathrm{H}_{42} \mathrm{~N}_{3} \mathrm{O}_{4}{ }^{+}, 604.3170$; HRMS found, 604.3180. (Supporting Materials, Figures S1-S3).

\subsection{Experimental Procedure for X-ray Crystallographic Analysis}

Crystallographic data of complexes were collected at $296 \mathrm{~K}$ on a Bruker APEX-II CCD system equipped with graphite-monochromated Mo-K $\alpha$ radiation $(\lambda=0.071073 \mathrm{~nm})$ using the $\omega-\varphi$ scan technique. Diffraction data were integrated using the SAINT program, which was also used for intensity corrections for Lorentz and polarization effects. A semi-empirical absorption correction was applied using SADABS. The structures were solved by direct methods, and all non-hydrogen atoms were refined anisotropically on F2 by full-matrix least-squares using the SHELXL-97 crystallographic 
software package. Summary of Data CCDC 969599, Compound Name: Formula: $\mathrm{C}_{39} \mathrm{H}_{44} \mathrm{~N}_{3} \mathrm{O}_{4}$, Unit Cell Parameters: a 12.5467(15) b 22.338(3) c 12.0855(14) P21/c.

\subsection{Stock Solution Preparation for Spectral Detection}

Stock solutions $\left(10^{-2} \mathrm{M}\right)$ of the chlorides or nitrate salts of $\mathrm{Mg}^{2+}, \mathrm{Sn}^{2+}, \mathrm{Cr}^{3+}, \mathrm{Ag}^{+}, \mathrm{Ca}^{2+}, \mathrm{Na}^{+}, \mathrm{Pb}^{2+}$, $\mathrm{K}^{+}, \mathrm{Mn}^{2+}, \mathrm{Zn}^{2+}, \mathrm{Cu}^{2+}, \mathrm{Cd}^{2+}, \mathrm{Li}^{+}, \mathrm{Hg}^{2+}, \mathrm{Al}^{3+}, \mathrm{Ba}^{2+}, \mathrm{Fe}^{2+}, \mathrm{Co}^{2+}, \mathrm{Sn}^{4+}$ and $\mathrm{Fe}^{3+}$ in $\mathrm{MeOH} / \mathrm{H}_{2} \mathrm{O}(2: 3, \mathrm{v} / \mathrm{v})$ were prepared. Stock solutions $\left(10^{-3} \mathrm{M}\right)$ of RBAP were prepared in $\mathrm{THF} / \mathrm{methanol} / \mathrm{H}_{2} \mathrm{O}(5: 2: 3, \mathrm{v} / \mathrm{v} / \mathrm{v})$. RBAP working solutions were freshly prepared by diluting the high concentration stock solution to the desired concentration prior to spectroscopic measurements.

\subsection{Computational Studies}

Computational studies were carried out to investigate the nature of $\mathrm{Sn}^{2+}$ coordination with RBAP using the Gaussian software package. All geometries for RBAP and RBAP-Sn ${ }^{2+}$ were optimized using $a b$ initio HF and density functional theory (DFT) calculations. The geometries were first optimized at the HF/3-21G level. The resulting structures were further optimized by DFT calculations using B3LYP with larger basis sets, i.e., the SDDAll basis set for $\mathrm{Sn}^{2+}$ and $6-31+\mathrm{G}(\mathrm{d})$ for all other atoms in the complex.

\section{Conclusions}

In conclusion, we report a rhodamine $\mathrm{B}$ derivative, RBAP, which is a selective and sensitive chemosensor that specifically recognizes the $\mathrm{Sn}^{2+}$ ion in a $\mathrm{MeOH} / \mathrm{H}_{2} \mathrm{O}(2: 3, \mathrm{v} / \mathrm{v}, \mathrm{pH}$ 5.95) solution by UV/vis and fluorescence spectroscopy. The chemical structure of RBAP was analyzed by ${ }^{1} \mathrm{H}-\mathrm{NMR}$, ${ }^{13} \mathrm{C}-\mathrm{NMR}$, and HRMS, and its structure was further confirmed by X-ray analysis. The 1:1 coordination mode was proposed on the basis of Job's plot. The $\mathrm{Sn}^{2+}$ binding ability of RBAP was further demonstrated by DFT calculations, which suggested that both the HOMO and LUMO orbitals in the RBAP-Sn ${ }^{2+}$ complex were stabilized and that the optical detection resulted from the significant decrease in the HOMO-LUMO energy gap.

\section{Supplementary Materials}

Supplementary materials can be accessed at: http://www.mdpi.com/1420-3049/19/6/7817/s1.

\section{Acknowledgments}

This research was supported by NSF China (81371616), the Natural Science Foundation of Jiangsu Province (No. BK2011704), the Fundamental Research Funds for the Central Universities (30920130111024, NO. 2011ZDJH08) and the Research Fund for the Doctoral Program of Higher Education of China (20133219120020). We thank the NJUST Sensor Lab (Chief: Xueji Zhang, Co-PI: Dan Shan and Jinming Kong) for providing facilities for the UV-Vis studies. 


\section{Author Contributions}

Xiaofeng Bao conceived and designed the experiments; Xiaowei Cao, Yanyan Jin, Xuemei Nie, and Baojing Zhou performed the experiments; Xiaofeng Bao analyzed the data and wrote the paper.

\section{Conflicts of Interest}

The authors declare no conflict of interest.

\section{References}

1. Guo, X.F.; Qian, X.H.; Jia, L.H. A highly selective and sensitive fluorescent chemosensor for $\mathrm{Hg}^{2+}$ in neutral buffer aqueous solution. J. Am. Chem. Soc. 2004, 126, 2272-2273.

2. Shiraishi, Y.; Sumiya, S.; Kohno, Y.; Hirai, T. A Rhodamine-cyclen conjugate as a highly sensitive and selective fluorescent chemosensor for $\mathrm{Hg}(\mathrm{II})$. J. Org. Chem. 2008, 73, 8571-8574.

3. Tian, M.Z.; Hu, M.M.; Fan, J.L.; Peng, X.J.; Wang, J.-Y.; Sun, S.G.; Zhang, R. Rhodamine-based "turn-on" fluorescent probe for $\mathrm{Cu}(\mathrm{II})$ and its fluorescence imaging in living cells. Bioorg. Med. Chem. Lett. 2013, 23, 2916-2919.

4. Wu, D.; Huang, W.; Duan, C.; Lin, Z.; Meng, Q. Highly sensitive fluorescent probe for selective detection of $\mathrm{Hg}^{2+}$ in DMF aqueous media. Inorg. Chem. 2007, 46, 1538-1540.

5. Yin, S.; Leen, V.; van Snick, S.; Boens, N.; Dehaen, W. A highly sensitive, selective, colorimetric and near-infrared fluorescent turn-on chemosensor for $\mathrm{Cu}^{2+}$ based on BODIPY. Chem. Commun. 2010, 46, 6329-6331.

6. Goswami, S.; Aich, K.; Das, S.; Das, A.K.; Manna, A.; Halder, S. A highly selective and sensitive probe for colorimetric and fluorogenic detection of $\mathrm{Cd}^{2+}$ in aqueous media. Analyst 2013, 138, 1903-1907.

7. Goswami, S.; Das, S.; Aich, K.; Sarkar, D.; Mondal, T.K.; Quah, C.K.; Fun, H.K. CHEF induced highly selective and sensitive turn-on fluorogenic and colorimetric sensor for $\mathrm{Fe}^{3+}$. Dalton Trans. 2013, 42, 15113-15119.

8. Bannon, D.I.; Chisolm, J.J. Anodic stripping voltammetry compared with graphite furnace atomic absorption spectrophotometry for blood lead analysis. Clin. Chem. 2001, 47, 1703-1704.

9. Hill, S.J.; Chenery, S.; Dawson, J.B.; Evans, E.H.; Fisher, A.; Price, W.J.; Smith, C.M.M.; Sutton, K.L.; Tyson, J.F. Advances in atomic emission, absorption and fluorescence spectrometry, and related techniques. J. Anal. At. Spectrom. 2000, 15, 763-805.

10. Resano, M.; Vanhaecke, F.; de Loos-Vollebregt, M.T.C. Electrothermal vaporization for sample introduction in atomic absorption, atomic emission and plasma mass spectrometry-a critical review with focus on solid sampling and slurry analysis. J. Anal. At. Spectrom. 2008, 23, $1450-1475$.

11. Vadillo, J.M.; Garcia, C.C.; Alcantara, J.F.; Laserna, J.J. Thermal-to-plasma transitions and energy threshold in laser ablated metals monitored by atomic emission/mass spectrometry coincidence analysis. Spectrochim. Acta Part B At. Spectrosc. 2005, 60, 948-954. 
12. Romao, W.; Lalli, P.M.; Franco, M.F.; Sanvido, G.; Schwab, N.V.; Lanaro, R.; Costa, J.L.; Sabino, B.D.; Bueno, M.I.M.S.; de Sa, G.F.; et al. Chemical profile of meta-chlorophenylpiperazine (m-CPP) in ecstasy tablets by easy ambient sonic-spray ionization, X-ray fluorescence, ion mobility mass spectrometry and NMR. Anal. Bioanal. Chem. 2011, 400, 3053-3064.

13. Van Meel, K.; Smekens, A.; Behets, M.; Kazandjian, P.; van Grieken, R. Determination of platinum, palladium, and rhodium in automotive catalysts using high-energy secondary target X-ray fluorescence spectrometry. Anal. Chem. 2007, 79, 6383-6389.

14. Forzani, E.S.; Zhang, H.Q.; Chen, W.; Tao, N.J. Detection of heavy metal ions in drinking water using a high-resolution differential surface plasmon resonance sensor. Environ. Sci. Technol. 2005, 39, 1257-1262.

15. Rojas, E.; Herrera, L.A.; Poirier, L.A.; Ostrosky-Wegman, P. Are metals dietarycarcinogens? Mutat. Res. 1999, 443, 157-181.

16. Unal, U; Somer, G. Simultaneous determination of trace $\mathrm{Sn}(\mathrm{II})$ and $\mathrm{Sn}(\mathrm{IV})$ using differential pulse polarography and application. Turkish J. Chem. 2011, 35, 73-85.

17. Braga, A.C.S.; Oliveira, M.B.N.; Feliciano, G.D.; Reiniger, I.W.; Oliveira, J.F.; Silva, C.R.; Bernardo, M. The effect of drugs on the labeling of blood elements with technetium-99m. Curr. Pharm. Des. 2000, 6, 1179-1191.

18. Viau, C.M.; Guecheva, T.N.; Sousa, F.G.; Pungartnik, C.; Brendel, M.; Saffi, J.; Pegas Henriques, J.A. $\mathrm{SnCl}_{2}$-induced DNA damage and repair inhibition of MMS-caused lesions in V79 Chinese hamster fibroblasts. Arch. Toxicol. 2009, 83, 769-775.

19. Bao, X.; Liu, D.; Jin, Y.; Liu, X.; Jiang, W. Design and synthesis of a novel Rhodamine B [2] rotaxane. RSC Adv. 2013, 3, 6783-6786.

20. Biswal, B.; Bag, B. Preferences of rhodamine coupled (aminoalkyl)-piperazine probes towards $\mathrm{Hg}$ (II) ion and their FRET mediated signaling. Org. Biomol. Chem. 2013, 11, 4975-4992.

21. Duong Tuan, Q.; Kim, J.S. Chromogenic chemodosimeters for heavy metal ion detection in solution and biospecimens. Chem. Rev. 2010, 110, 6280-6301.

22. Kim, H.N.; Lee, M.H.; Kim, H.J.; Kim, J.S.; Yoon, J. A new trend in rhodamine-based chemosensors: Application of spirolactam ring-opening to sensing ions. Chem. Soc. Rev. 2008, $37,1465-1472$.

23. Kwon, J.Y.; Jang, Y.J.; Lee, Y.J.; Kim, K.M.; Seo, M.S.; Nam, W.; Yoon, J. A highly selective fluorescent chemosensor for $\mathrm{Pb}^{2+}$. J. Am. Chem. Soc. 2005, 127, 10107-10111.

24. Liu, J.; Wu, D.; Yan, X.; Guan, Y. Naked-eye sensor for rapid determination of mercury ion. Talanta 2013, 116, 563-568.

25. Ni, J.; Li, Q.; Li, B.; Zhang, L. A novel fluorescent probe based on rhodamine B derivative for highly selective and sensitive detection of mercury(II) ion in aqueous solution. Sens. Actuat. B Chem. 2013, 186, 278-285.

26. Yang, H.; Zhou, Z.; Huang, K.; Yu, M.; Li, F.; Yi, T.; Huang, C. Multisignaling optical-electrochemical sensor for $\mathrm{Hg}^{2+}$ based on a rhodamine derivative with a ferrocene unit. Org. Lett. 2007, 9, 4729-4732.

27. Yu, M.; Shi, M.; Chen, Z.; Li, F.; Li, X.; Gao, Y.; Xu, J.; Yang, H.; Zhou, Z.; Yi, T.; et al. Highly sensitive and fast responsive fluorescence turn-on chemodosimeter for $\left.\mathrm{Cu}^{2+}\right)$ and its application in live cell imaging. Chemistry 2008, 14, 6892-6900. 
28. Chen, X.; Pradhan, T.; Wang, F.; Kim, J.S.; Yoon, J. Fluorescent chemosensors based on spiroring-opening of xanthenes and related derivatives. Chem. Rev. 2012, 112, 1910-1956.

29. Goswami, S.; Manna, A.; Maity, A.K.; Paul, S.; Das, A.K.; Das, M.K.; Saha, P.; Quah, C.K.; Fun, H.-K. Selective detection and bio-imaging of $\mathrm{Pd}^{2+}$ with novel "C-CN" bond cleavage of cyano-rhodamine, cyanation with diaminomaleonitrile. Dalton Trans. 2013, 42, 12844-12848.

30. Mahapatra, A.K.; Manna, S.K.; Mandal, D.; Das Mukhopadhyay, C. Highly sensitive and selective rhodamine-based "off on" reversible chemosensor for tin $\left(\mathrm{sn}^{4+}\right)$ and imaging in living cells. Inorg. Chem. 2013, 52, 10825-10834.

31. Liu, D.; Pang, T.; Ma, K.; Jiang, W.; Bao, X. A new highly sensitive and selective fluorescence chemosensor for $\mathrm{Cr}^{3+}$ based on rhodamine $\mathrm{B}$ and a 4,13-diaza-18-crown 6-ether conjugate. RSC Adv. 2014, 4, 2563-2567.

Sample Availability: Samples of the compounds $\mathbf{2}$ and RBAP are available from the authors.

(C) 2014 by the authors; licensee MDPI, Basel, Switzerland. This article is an open access article distributed under the terms and conditions of the Creative Commons Attribution license (http://creativecommons.org/licenses/by/3.0/). 